\title{
The Leadership Role of The Principal in Increasing Admission of New Students
}

\author{
Muhammad Mulya Al-Amien \\ Universitas Ahmad Dahlan \\ muhammadmuliyaalamien@gmail.com
}

\author{
Achadi Budi Santosa \\ Universitas Ahmad Dahlan \\ budi.santosa@mp.uad.ac.id
}

\begin{abstract}
This study aims to reveal the role of school principals in increasing new student admissions. The method used in this research is qualitative. Collecting data through documentation, observation, and interviews. Respondents include school principals, vice principals, and heads of expertise programs. The results showed that the principal's role in increasing new student admissions was to optimize his function as an educator, which is to always provide guidance, as a manager who always encourages teachers and education personnel, especially those who are included in the committee to carry out their duties in accordance with the plans and rules that have been outlined. In its main duties and functions. As a supervisor, the school principal always monitors, provides input, direction, and motivation to all members of the new student admissions program committee. The principal is also always a role model in discipline, and is always active in establishing relationships with junior high schools in his area. The results of this study are certainly quite inspiring, because the implications can encourage the spirit of school principals in improving the performance of the new student admissions committee in each school.
\end{abstract}

Keywords: Role Model; Principal; Task Group; Admission

Abstrak: Penelitian ini bertujuan untuk mengungkap peran kepala sekolah dalam meningkatkan penerimaan siswa baru. Metode yang digunakan dalam penelitian ini adalah kualitatif. Pengumpulan data melalui dokumentasi, observasi, dan wawancara. Responden meliputi kepala sekolah, wakil kepala sekolah, dan kepala program keablian. Hasil penelitian menunjukkan bahwa peran kepala sekolab dalam meningkatkan penerimaan siswa baru adalah dengan mengoptimalkan fungsinya sebagai pendidik, yaitu senantiasa memberikan bimbingan, sebagai manager yang senantiasa mendorong para guru dan tenaga kependidikan khususnya yang masuk dalam kepanitiaan untuk melaksanakan tugasnya sesuai dengan perencanaan dan aturan yang telah dituangkan dalam tugas pokok dan fungsinya. Sebagai supervisor, kepala sekolah selalu melakukan monitoring, memberikan masukan, arahan, dan motivasi terbadap semua anggauta panitia program penerimaan siswa baru. Kepala sekolah juga senantiasa menjadi teladan dalam kedisiplinan, dan selalu aktif menjalin bubungan dengan sekolah menengah pertama yang ada di wilayahnya. Hasil penelitian ini tentu cukup inspiratif, karena implikeasinya dapat mendorong semangat para kepala sekolah dalam meningkatkan kinerja panitia penerimaan siswa baru di setiap sekolah.

Kata Kunci: Peran; Kepala Sekolab; Kelompok Tugas; Penerimaan 


\section{INTRODUCTION}

Education is a conscious effort that is deliberately designed to achieve predetermined goals (Yusdiana, 2018). The purpose of education is to make human resources even better (Smith, 2013). Various efforts to improve the quality of human resources, one of which is through education through the process of teaching and learning activities in schools (Bakkenes et al., 2010). In choosing a school, to meet the educational needs of the community, they will choose a quality school that is in accordance with their wishes (Mukhtar, 2015). Schools must be able to provide good quality and quality in their management, because they will become a reference for the community, especially prospective students to continue their education level.

Admission of new students, especially in vocational high schools (SMK) is the process of finding, determining, and attracting prospective students to become students in the educational institution concerned (Rahmanto, 2017). New Student Admission (PPDB) is a program that is routinely carried out by each school every new academic year. Each school prepares a PPDB program with a fairly long period of time. the purpose of PPDB is to fulfill the allocation of the number of new students in accordance with the target and the capacity of the school. PPDB is an opportunity for schools to find and recruit prospective students who have potential, both in the fields of academics, arts, and sports, so that they can increase the potential of the school externally and internally (Brown, 1992; Bruggink \& Gambhir, 1996). Various kinds of strategies in vocational high schools (SMK) are raised in order to be able to compete with other schools in a healthy manner. Usually, SMKs, especially those managed by the private sector, will focus the PPDB program well in order to achieve maximum results.

The main problem faced in PPDB in general is the low public interest in registering their children to SMK. The stigma of some people that SMK will only produce unskilled workers, cannot continue to college, and tends to be filled by low-ability students. Therefore, to get a good and maximum achievement in the implementation of the PPDB program, the leadership role of the principal is very important (Ellrich, 2014; Valeriu, 2015; Zaib \& Harun, 2014). The principal should be able to make a good contribution to his school in increasing the acceptance of new students. A school principal must at least be able to improve and maintain his achievements in accepting new students for the last 5 years.

Acceptance of new students is a recruitment activity at educational institutions, prospective students will be screened, selected through entrance 
tests (Veloutsou et al., 2004; Wechsler, 2017). Prospective students who pass are those who meet the criteria previously determined by the school. The stages that new students must go through after passing the selection are re-registration, only after that can they be officially accepted (Kurnia et al., 2019). Admission of new students is one of the most important school programs during the new school year.

The role of the principal is very important for the increasing number of new students who will enroll in schools, the increasing number of students in a school cannot be separated from school branding which is generally closely related to quality factors (Cheng et al., 2016; Folta et al., 2018). The quality of a good school is not only determined by the educational input in the form of students but also by the role of the teacher who is responsible for the education process (Cenkseven-Onder \& Sari, 2009; Davis, 2001). On the other hand, the principal also has a big responsibility in promoting and coordinating teachers and employees to make the new student admission program a success (Kurnia et al., 2019).

\section{METHODS}

This study uses a qualitative technique with a research setting in Muhammadiyah Vocational School, Imogiri. While the object of research is the leadership role of the principal in increasing the number of new student admissions. The data collection techniques used interview, documentation, and participant observation. In-depth interviews were conducted to gain a better and more comprehensive understanding if there were insufficient observational data. Through participatory observation, researchers carefully observe every activity, event, and what they say and their role in the organization (Djam'an \& Aan, 2010).

Because the purpose of this study is to reveal new student admissions activities, the research subjects focus more on the PPDB (New student registration) committee which includes the principal, all vice principals, the head of the expertise program and several teachers who are members of the PPDB task team. This research begins with direct observation of the preparation of the PPDB which will be carried out from May to July 2021, which includes; observing the involvement of the participants in the preparation for the new student registration meeting, the process of the preparatory meeting and the results of the meeting decisions; observing the clarity of information and directions given by the principal, including attitude, openness and attention to 
meeting participants; observe the extent of the responses of meeting participants in the meeting; observing the activities of monitoring the development of prospective new students by the principal; and also the results of the evaluation of the implementation of PPDB.

The review of administrative documents is carried out by reading PPDB supporting documents, including: guest book of prospective new students for the 2020/2021 academic year; new student registration book 2020/2021; PPDB 2020/2021 meeting agenda book; recapitulation book of prospective new students who have re-registered; and PPDB documents 2016/2017 to $2020 / 2021$.

Questions related to the planning, preparation, and implementation of PPDB were carried out in depth, both in official situations, attending team meetings, or informally. Questions are addressed to committee members who are directly involved in PPDB activities. The goal is to produce natural results. The themes of the questions include: preparation of PPDB activities; the role of the principal in planning, preparing, monitoring, and evaluating PPDB activities; meeting materials led by the Principal; perceptions of the principal's personality; and the principal's social relations.

\section{RESULTS AND DISCUSSION}

The increase in the number of students at SMK Muhammadiyah Imogiri is quite stable, not too many but continuously every year. This condition is inseparable from the leadership role of the principal which is quite influential in efforts to increase the number of students. The principal prepares plans through the school promotion task team and the new student admissions team (PPDB), makes standard operating procedures (SOP), and implements promotion patterns by involving school members including teachers, employees, and students. Data on new student admissions for 2016-2020 can be seen in figure 1 below; 


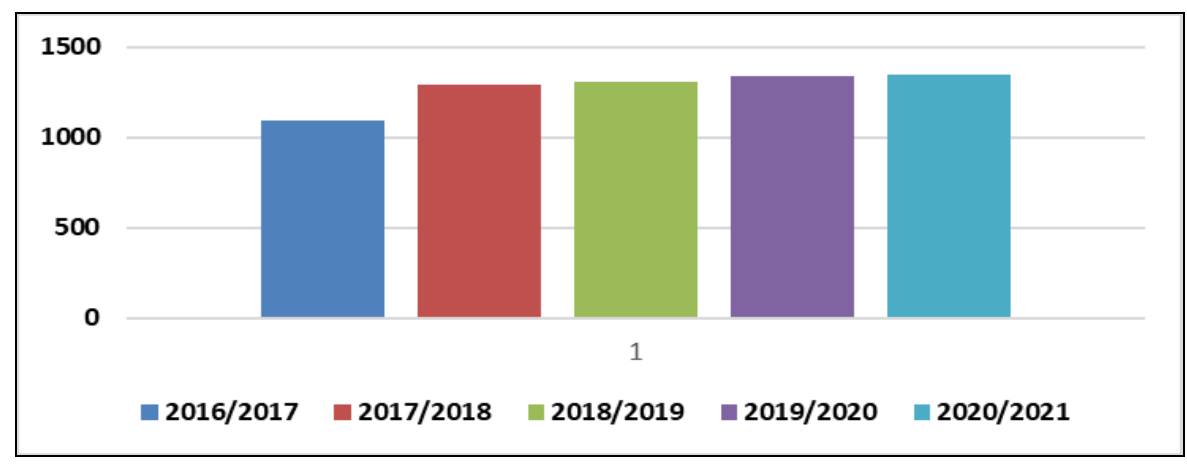

Figure 1

Progress of New Student Admission for 5 Years

From the picture above, it can be seen that the increase in the number of new students is quite stable, although the increase is not significant. The results of the interview with SA confirmed that the procedure for accepting new students was in accordance with standard operating procedures (SOPs) which were designed through an internal quality assurance system (SPMI) that had been mutually agreed upon. The PPDB program begins with the formation of a promotion team by the deputy head of student affairs. As stated by SA; "The planning of the routine program for new student admissions begins with an assignment to the vice principal for student affairs, namely WP to form a school promotion team, then the school promotion team formulates promotional programs in a coordinated manner...". This is also supported by the WP's statement which states that the principal always initiates the formation of a school promotion team ahead of the PPDB implementation. The promotion team consisted of several teachers and employees who were considered to have good capacity and dedication in their role in PPDB last year. As can be seen in table 1 below;

Table 1

School Admission Task Team

\begin{tabular}{clll}
\hline No & \multicolumn{1}{c}{ Name } & \multicolumn{1}{c}{ Position } & \multicolumn{1}{c}{ Team Task } \\
\hline 1 & SA & KS & Person responsible \\
\hline 2 & WP & WKS 2 & chairman \\
\hline 3 & SS & WKS 1 & Secretary \\
\hline 4 & HS & WKS 4 & treasurer \\
\hline 5 & EA & WKS 3 & Data Collection Choir \\
\hline 6 & TY & Auto Teacher & Media \& IT Choir \\
\hline 7 & FAN & BK teacher & Open School Choir \\
\hline
\end{tabular}


After the formation of the promotion team, the core team formulates school promotion strategies by always coordinating with the principal. The role of the promotion team in making programs is to promote the school, either directly or indirectly. This activity is always monitored by the principal on a regular basis. according to the principal's report; "Yes, indeed we always monitor the promotion team's program and I always give encouragement to achieve team effectiveness, so that when the assignment ends and is delegated to the PPDB team, we already have a solid foundation...". The Promotion Team with the direction of the principal always tries to record prospective students every month of their assignment. The incoming data is then followed up with intense communication until the acceptance of new students is officially opened.

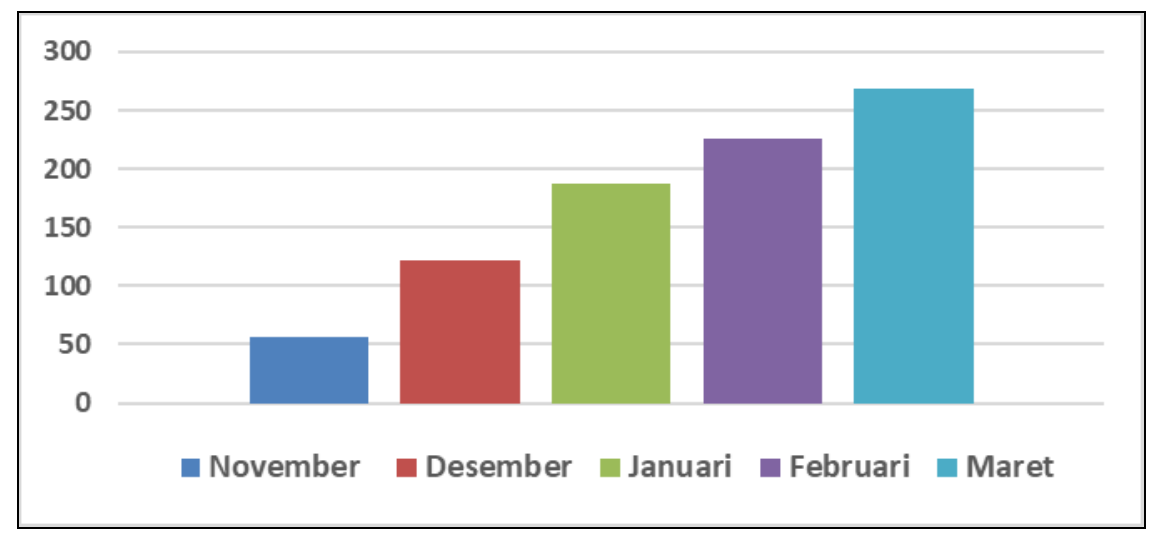

Figure 2

Data on Increase in Prospective Registrants for 5 months

After the promotion team finished working for a period of 5 months, an official PPDB team was formed according to the SOP that had been agreed upon together. The PPDB team was formed through the recommendation of the principal together with the deputy head of student affairs and public relations.

The process of implementing the PPDB program is carried out after the assignment from the school promotion team ends and is submitted to the deputy head of student affairs for further preparation of a report to the school principal. As stated by WP through interviews; "After completing the assignment from the promotion team, I immediately reported to the headmaster and immediately evaluated and formulated the next strategy for the PPDB team which was formed from the development of the promotion team, so we formed a PPDB team consisting of the promotion team and employee teachers who we 
appointed through a decree (SK) Principal regarding the formation of the PPDB team..." After the task team was formed, the head of PPDB together with the principal as the person in charge of the activities, divided the tasks to teachers and employees into several groups/divisions.

The PPDB team is divided into several divisions, under the coordination of the school principal, formulates the PPDB registration flow which is then set into rules. According to SS who happens to be the deputy principal of the school, that "The registration process has been arranged to serve prospective new students to receive continuous information. Starting from the secretariat section which makes invitation letters for new prospective students who have been recorded by the data division of the promotion team to conduct verification and vocational mapping tests, then new prospective students do the filing and re-registration according to their respective majors....". This registration flow chart will be affixed to the information and media division to serve as directives/instructions for prospective new students to register. The following is a picture of the registration flow at SMK Muhammadiyah Imogiri;

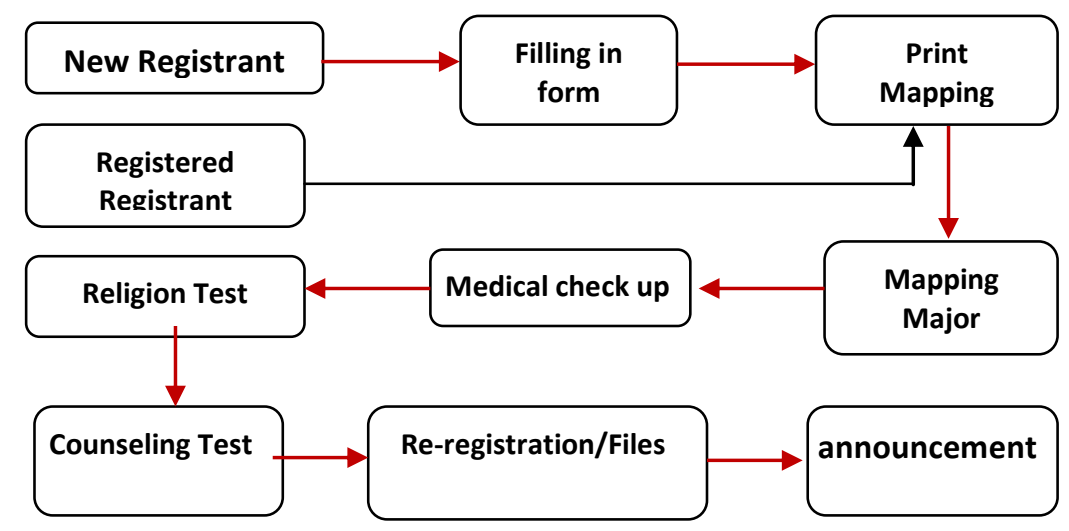

Figure 3

New Student Registration Flow

The implementation of new student admissions is always monitored and evaluated by the principal. HA as the coordinator of the departmental mapping test and the head of the automotive light vehicle engineering department stated that every PPDB process and development is always monitored by the school principal. Every day the school principal saw firsthand and asked for progress reports. In line with $\mathrm{HA}$, the vice principal for public relations and industry explained that the report in the form of monitoring data was in accordance with 
the administrative records of each division. For example, a division reports the progress of students who have re-registered in full or who are still in installments, as well as other divisions who receive the same data. The entire process of activities is carried out procedurally and monitored every day.

Based on the results of interviews with EA as the coordinator of the registration field, he said that the admission of new students cannot be separated from the role of the principal as a manager and leader who always monitors from preparation, process, implementation to solving problems encountered when PPDB takes place. The principal is a figure who always appears to be a good listener for various kinds of complaints and problems that occur. Humanist and democratic leadership is always applied by the principal, the total attention given while being in charge of various school programs and activities is the capital to achieve success in accepting new students. No less important factor is the superior human resources who are relatively young to provide the best and fast service in the program. As stated by SA that "I feel very helpful to have a good team at work who are still relatively young on average...".

The various programs carried out are no exception for PPDB, there are always obstacles or obstacles, either directly or indirectly. Obstacles experienced include the lack of capable resources in the use of information technology as a tool in the PPDB program, so that the registration process is forced to use 2 channels, namely through printed forms and online forms. As explained by KG as the coordinator of the mapping test of the network computer engineering department (TKJ) as well as the head of the department who stated that the IT staff and TKJ teachers were limited in number, only 5 teachers, and even then not all of them were competent in the internet, so that the use of IT in the PPDB program until now not optimal. According to KG, for the success of PPDB activities, solid cooperation between leaders and teachers must work hard in order to achieve the set student targets. Efforts are being made to improve the limited capacity of resources by conducting coordination meetings, briefings and workshops. However, it is realized that there are still internal problems that cannot be overcome, namely there are still some teachers who have not supported the success of the program made by the school. HS, one of the deputy heads of public relations and industry, stated that every teacher should want to be involved in PPDB activities for the success of school goals. briefings and workshops. However, it is realized that there are still internal problems that cannot be overcome, namely there are still some teachers who have not 
supported the success of the program made by the school. HS, one of the deputy heads of public relations and industry, stated that every teacher should want to be involved in PPDB activities for the success of school goals. briefings and workshops. However, it is realized that there are still internal problems that cannot be overcome, namely there are still some teachers who have not supported the success of the program made by the school. HS, one of the deputy heads of public relations and industry, stated that every teacher should want to be involved in PPDB activities for the success of school goals.

The principal has a function as a manager in his school, this shows that a principal must have various strategies to empower teachers and employees with good cooperation and mutual support (Setyawan \& Santosa, 2021; Wening \& Santosa, 2020). In a school, a principal must plan, implement, lead, and be supervised in accordance with applicable procedures (Rusmawati, 2013). As done by SA as the principal, he always tries to prioritize cooperation and always puts the right people in the right place. This was shown by the principal in the selection of the promotion team, until the new student admissions team was carried out by appointing teachers who were highly dedicated to the school, indicated by the activeness of the teachers in promoting the school and seeking students in previous years.

The principal's leadership is a very decisive factor in the success or failure of the process of accepting new students. Leadership is the process of influencing people or groups of people in an organization in order to realize common interests and goals (Ali, 2012; Gurr et al., 2006; Platow et al., 2015). Success or failure to achieve organizational goals is determined by a person in managing leadership style and resource management (Febriansyah, 2016). The determination of leadership is determined by the style and disposition carried out by the principal. The principal is a teacher who meets certain requirements and is given an assignment as a principal.

Principals in Indonesia have a term of office in each period. The length of the period is 4 years in one term and can be extended for a second period when judged to be good at managing and leading the school. Principals need to have integrity, passion and a strong desire to develop themselves (Covey, 1992; Gurr et al., 2006; Nasution, 2017). From the various definitions of leadership mentioned above, it can be interpreted that leadership involves a process of social influence that can influence a person or group to provide direction or structure for activities and group or organizational relationships (Yuliani \& Kristiawan, 2017). 
Administrative activities are very important in order to support the smooth implementation of activities and the achievement of the goals of new student admissions activities (Kavoosi et al., 1995; Kirillov et al., 2015). The principal must be able to master administration well because he is very close to various management, preparation, and development activities (Zepeda, 2014). The principal as an administrator must be able to manage management well, including the management of authority and the use of appropriate and proportional budgets (Juliantoro, 2017). According to WP as deputy head of student affairs, SA as principal is very concerned about following all applicable rules, he gave an example of giving an assignment as head of PPDB, SA has never passed the procedures described in the assignment SOP, such as giving authority and assigning the formation of a PPDB team to the deputy head of student affairs and related to community relations. Efforts to increase capacity by principals are actually not only limited to new student admissions, regular supervision has also been carried out on teachers, this activity is generally also intended to improve the quality of educational activities in schools (Maduratna, 2013). Its activities are usually in the form of planned and systematic supervision or monitoring of teachers and employees by providing encouragement and guidance (Books et al., 2021), and good cooperation, in order to create common goals in a conducive work environment.

In the new student admission program, the principal has carried out his supervisory role quite well, this is as stated by EA as the coordinator of the school registration team. EA said that supervision, either directly or indirectly, was carried out by school principals, among others, by requesting reports on the progress of educational activities every day, and plans for follow-up on the results of supervision. After that, an evaluation is carried out and a careful planning for the future is carried out. Supervision leadership by the principal is very influential on the direction and future of the school (Books et al., 2021). The efforts of the principal in influencing, guiding, fostering, and mobilizing the entire school community are quite successful. A good leader is a leader who successfully leads members to achieve the goals that have been set together (Purwanti, 2013). The principal is also able to consistently maintain the success of new student admissions. As stated by WP as the head of the PPDB team, that PPDB has been successful for 4 consecutive years because of the leadership and good cooperation between the school principal and the entire PPDB team. 


\section{CONCLUSION}

The principal plays a fairly active role in PPDB activities, namely always providing guidance, as a manager who always encourages teachers and education personnel, especially those who are included in the committee to carry out their duties in accordance with the plans and rules that have been outlined in their main tasks and functions. As a supervisor, the school principal always monitors, provides input, direction, and motivation to all members of the new student admissions program committee. The principal also always provides an example in discipline, and is always active in establishing relationships with junior high schools in his area. The principal is a figure who always appears to be a good listener for various kinds of complaints and problems that occur. Humanist and democratic leadership is always applied by the principal, the total attention given while being in charge of various school programs and activities is the capital to achieve success in accepting new students.

The results of this study are certainly quite inspiring, because the implications can encourage the spirit of school principals in improving the performance of the new student admissions committee in each school. However, like other studies, this research is also not free from limitations, because the social setting of this research only covers one school, of course its application cannot be carried out in other schools, it needs understanding and adjustment to the social conditions of the school.

\section{REFERENCE}

Ali, A. (2012). Leadership and its influence in organizations-a review of intellections. International Journal of Learning and Development, 2(6), 73-85.

Bakkenes, I., Vermunt, JD, \& Wubbels, T. (2010). Teacher learning in the context of educational innovation: Learning activities and learning outcomes of experienced teachers. Learning and Instruction, 20(6), 533548.

Brown, LB (1992). Student admission and multicultural recruitment. Journal of Library Administration, 16(1-2), 109-122.

Bruggink, TH, \& Gambhir, V. (1996). Statistical models for college admission and enrollment: A case study for a selective liberal arts college. Research in Higher Education, 37(2), 221-240.

Buku, K., Santosa, AB, Sukirman, S., \& Hasanah, E. (2021). The Effect of Principal's Leadership and Supervision Competencies on Junior High 
School Teacher Performance in Nagekeo District. Edumaspul: Journal of Education, 5(1), 530-540.

Cenkseven-Onder, F., \& Sari, M. (2009). The Quality of School Life and Burnout as Predictors of Subjective Well-Being among Teachers. Educational Sciences: Theory and Practice, 9(3), 1223-1235.

Cheng, A., Trivitt, JR, \& Wolf, PJ (2016). School choice and the branding of Milwaukee private schools. Social Science Quarterly, 97(2), 362-375.

Covey, SR (1992). Principle centered leadership. Simon and Schuster.

Davis, HA (2001). The quality and impact of relationships between elementary school students and teachers. Contemporary Educational Psychology, 26(4), 431-453.

Djam'an, S., \& Aan, K. (2010). Qualitative research methodology. Bandung: Alphabeta, 28.

Ellrich, LM (2014). Are SAT scores a strong predictor of student success? A study of education majors, admission variables and the impact of leadership development.

Febriansyah. (2016). Realizing Professional Human Resources in Global Competence. Proceedings of the National Seminar on Education, 570577.

Folta, SC, Koch-Weser, S., Tanskey, LA, Economos, CD, Must, A., Whitney, C., Wright, CM, \& Goldberg, JP (2018). Branding a school-based campaign combining healthy eating and eco-friendliness. Journal of Nutrition Education and Behavior, 50(2), 180-189.

Gurr, D., Drysdale, L., \& Mulford, B. (2006). Models of successful principal leadership. School Leadership and Management, 26(4), 371-395.

Juliantoro, OM (2017). The Principal's Role in Improving the Quality of Education. 5(2).

Kavoosi, MC, Elman, NS, \& Mauch, JE (1995). Faculty mentoring and administrative support in schools of nursing. SLACK Incorporated Thorofare, NJ.

Kirillov, AV, Vinichenko, MV, Melnichuk, AV, Melnichuk, YA, \& Lakina, Y. (2015). Higher education institutions grading: administrative and support personnel. International Journal of Economics and Financial Issues, 5(3S), 173-182.

Kurnia, IH, Santoso, D., et al, Satria, R., Supriyanto, A., Timan, A., Adha, MA, 
Hatijah, F., Sholeh, M., Zuhriyo Dwi Yazid Zamakhsyah, S., Elyus, DS, Qohar, MA, Puspita, Y., Lestari, Y., Marta, R., Alivermana, W., Safii, R., Noviantiani, R., Harmonika, S., ... Widianto, A. (2019). The role of public relations in an effort to increase interest in the registration of new students. Altizam Journal, 1(1), 159-173.

Maduratna, M. (2013). The Role of Principal Leadership in Improving the Effectiveness of Teachers and Elementary Schools 015 Samarinda. EJournal of Public Administration, 1(1), 70-84.

Mukhtar. (nd). Principal's strategy in improving teacher performance at public junior high schools in Masjid Raya District, Aceh Besar District. 103-117.

Nasution, MK (2017). The use of learning methods in improving student learning outcomes. Studia Didactic: Scientific Journal of Education, 11(1), 9-16.

Platow, MJ, Haslam, SA, Reicher, SD, \& Steffens, NK (2015). There is no leadership if no-one follows: Why leadership is necessarily a group process. International Coaching Psychology Review, 10(1), 20-37.

Purwanti, S. (2013). The Principal's Leadership Role in Improving Teacher Work Discipline. 1(1), 210-224.

Rahmanto, W., \& Darmaji, A. (2017). The Strategy of the Head of Madrasah in Increasing New Student Acceptance in Min Melikan Rongkop Gunungkidul for the 2016/2017 Academic Year. 1-21.

Rusmawati, V. (2013). Principal's Leadership Role in Efforts to Improve Teacher Work Discipline at Sdn 018 Balikpapan. EJournal of Public Administration, 1(2), 395-409.

Setyawan, D., \& Santosa, AB (2021). Competence of Principals and Teachers as the Base for Achievement of Education Quality. Educational: Journal of Educational Sciences, 3(5), 3271-3281.

Smith, N. (2013). Educated guesses What is the purpose of education? Stimulus: The New Zealand Journal of Christian Thought and Practice, 20(3), 3235.

Valeriu, D. (2015). The Aspiration to Success in School and the Need for Performance of the Pupils. Procedia - Social and Behavioral Sciences, 180(November 2014), https:// doi.org/10.1016/j.sbspro.2015.02.158

$549-553$.

Veloutsou, C., Lewis, JW, \& Paton, RA (2004). University selection: information requirements and importance. International Journal of Educational 


\section{Management.}

Wechsler, HS (2017). The qualified student: A history of selective college admission in America. Routledge.

Wening, MH, \& Santosa, AB (2020). The principal's leadership strategy in facing the digital era 4.0. JMKSP (Journal of Management, Leadership, and Education Supervision), 5(1), 56-64.

Yuliani, T., \& Kristiawan, M. (2017). The Principal's Leadership Role in Fostering Social Competence (Prime Service) for School Administration Staff. JMKSP (Journal of Management, Leadership, and Education Supervision), 1(2), 122-132. https://doi.org/10.31851/jmksp.v1i2.1013

Yusdiana, BI, \& Hidayat, W. (2018). Analysis of the mathematical reasoning ability of high school students on the limit function material. 1(3), 409414. https://doi.org/10.22460/jpmi.v1i3.409-414

Zaib, Z., \& Harun, H. (2014). Leadership in technical and vocational education: towards excellence human capital. Leadership, 5(23).

Zepeda, SJ (2014). The principal as instructional leader: A handbook for supervisors. Routledge. 